\title{
Correction to: Arsenic nano complex induced degradation of YAP sensitized ESCC cancer cells to radiation and chemotherapy
}

\author{
Wei Zhou ${ }^{1 \dagger}$, Meiyue Liu' ${ }^{2 \dagger}$, Xia Li ${ }^{1}$, Peng Zhang ${ }^{1}$, Jiong Li ${ }^{3}$, Yue Zhao ${ }^{1 *}$, Guogui Sun ${ }^{2 *}$ and Weimin Mao ${ }^{{ }^{*}}$
}

\section{Correction to: Cell Biosci (2020) 10(1): 1-5 https://doi.org/10.1186/s13578-020-00508-x}

Following publication of the original article [1], the affiliation of the first two authors was incorrect. The affiliations are presented correctly in this correction article.

The original article has been corrected.

\begin{abstract}
Author details
${ }^{1}$ Cancer Hospital of University of Chinese Academy of Sciences (Zhejiang Cancer Hospital), Institute of Cancer and Basic Medicine of Chinese Academy of Sciences, Hangzhou 310022, China. ${ }^{2}$ North China University of Science and Technology Affiliated Peoples Hospital, School of Public Health, North China University of Science and Technology, Tangshan 063001, China.

${ }^{3}$ Department of Medicinal Chemistry, Massey Cancer Center, Philips Institute for Oral Health Research, Virginia Commonwealth University, Richmond, Virginia 23298-0540, United States.
\end{abstract}

Accepted: 6 January 2021

Published online: 19 January 2021

\section{Reference}

1. Zhou W, Liu M, Li X, Zhang P, Li J, Zhao Y, Sun G, Mao W. Arsenic nano complex induced degradation of YAP sensitized ESCC cancer cells to radiation and chemotherapy. Cell Biosci. 2020;10(1):1-5. https://doi. org/10.1186/s13578-020-00508-X.

\section{Publisher's Note}

Springer Nature remains neutral with regard to jurisdictional claims in published maps and institutional affiliations.

The original article can be found online at https://doi.org/10.1186/s1357 8-020-00508-x

\footnotetext{
*Correspondence: zhaoyue@zjcc.org.cn; guogui_sun2013@163.com; maowm@zjcc.org.cn

'Wei Zhou and Meiyue Liu contributed equally to the manuscript

${ }^{1}$ Cancer Hospital of University of Chinese Academy of Sciences (Zhejiang

Cancer Hospital), Institute of Cancer and Basic Medicine of Chinese

Academy of Sciences, Hangzhou 310022, China

${ }^{2}$ North China University of Science and Technology Affiliated Peoples

Hospital, School of Public Health, North China University of Science

and Technology, Tangshan 063001, China

Full list of author information is available at the end of the article
}

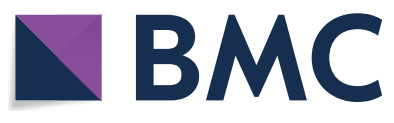
adaptation, distribution and reproduction in any medium or format, as long as you give appropriate credit to the original author(s) and the source, provide a link to the Creative Commons licence, and indicate if changes were made. The images or other third party material in this article are included in the article's Creative Commons licence, unless indicated otherwise in a credit line to the material. If material is not included in the article's Creative Commons licence and your intended use is not permitted by statutory regulation or exceeds the permitted use, you will need to obtain permission directly from the copyright holder. To view a copy of this licence, visit http://creativecommons.org/licenses/by/4.0/. The Creative Commons Public Domain Dedication waiver (http://creativecommons.org/publicdomain/zero/1.0/) applies to the data made available in this article, unless otherwise stated in a credit line to the data. 